\title{
THE EFFECT OF YEAST AND SOME MEDICINAL PLANTS AS GROWTH PROMOTERS ON KIDS IN NEW VALLEY GOVERNORATE
}

\author{
KHALWY A.M. ${ }^{1}$, ELNAKER Y.A. ${ }^{2}$ AND GALBAT S.A. ${ }^{3}$ \\ ${ }^{1}$ Researcher, Department of Animal Medicine, (Internal Veterinary Medicine) Faculty of Veterinary \\ Medicine, New Valley University, New Valley Governorate, El-Kharga Oasis \\ ${ }^{2}$ Department of Animal Medicine, (Infectious Diseases) Faculty of Veterinary Medicine, New Valley \\ University, New Valley Governorate, El-Kharga Oasis \\ ${ }^{3}$ Department of Animal Medicine, (Internal Veterinary Medicine) Faculty of Veterinary Medicine, \\ New Valley University, New Valley Governorate, El-Kharga Oasis
}

Received: 1 June 2021; Accepted: 30 June 2021

\begin{abstract}
Thirty castrated kids, aged 6-9 months and weighed on average 9-10 kg were divided into three groups (10 kids in each), named A, B and C. The experiment extended from August, 2020 to February, 2021. Animal management procedures included injection of prophylactic dose of broad spectrum anti-parasitic Ivermectin plus Clorsulon and monthly dipping of animals in solution of Deltamethrin. Kids in the B group were fed the basal ration (concentrate feed mixture plus Barseem hay without additives (Control), while those in the A and $\mathrm{C}$ groups were fed the same basal ration supplemented daily with 1 gram from yeast tablet, 2 caps of medicinal plants mixture. respectively. The feeding program was applied $4 \%$ of total calculated body weights of each group per day. Addition of yeast and medicinal plants to the diet of kids during months of experiment as compared to the control group significantly improved the final live body weight at the end of 4 months and daily body gain of kids. Supplementation improved the animal rumen function i.e. increased feed intake, appetite and number of micro flora populations and also kept the biochemical parameters of animals within normal physiological state that indicate their healthy status. On the other hand, Supplementations of kids negatively affect the concentrations of $\mathrm{Ca}$ and $\mathrm{Mg}$ and positively increase P levels. In conclusion, the use of nutritional yeast and medicinal plants in animal nutrition as feed additives has a beneficial effect on increasing animal production.
\end{abstract}

Keywords: growth promoters \& yeast \& medicinal plants \& kids

\section{INTRODUCTION}

Goats are considered one of the most beneficial animals in the world and widely known as the poor man's cow. These

Corresponding author: KHALWY A.M.

E-mail address: dr.ahmadkhalwy@gmail.com

Present address: Researcher, Department of Animal Medicine, (Internal Veterinary Medicine) Faculty of Veterinary Medicine, New Valley University, New Valley Governorate, El-Kharga Oasis animals are one of the earliest domesticated animals record in date back 10,000 years, which have gentle temperaments, making them ideal household animals (Rosalee et al., 2008). World populations of goats have increased in the last 50 years, while populations of other livestock have maintained or decreased. Current number has reached about 1 billion goats around the world. Asia and Africa have more than $90 \%$ of population and only $1.8 \%$ in Europe. High adaptability to the environment is one 
of the main breed characters for high production in these countries (Capote, 2014). In Egypt, there are approximately 3 million head of goats which are the most favorable farm animals that are able to withstand drought and in New Valley which is a remote-desert region. Goats are of great importance in meat, milk and hair productions and local income for farmers (Magdy, 2004).

Yeast is one of the microbial feed additives which is non-pathogenic microbes occurring in nature and in the gastrointestinal tract of ruminants. They exert a positive influence on the host physiology, improve nutrient synthesis and their bio-availability resulting in better growth performance in farm animals (Khalid et al., 2011). Supplements of yeast can significantly improve the performance of ruminants. Various beneficial effects have been reported include increased feed intake, milk production and weight gain (Ruf et al., 1953). Yeasts are most efficient for animals fed on high energy diets, which easily fermented by rumen microorganisms (Williams et al., 1991).

The use of herbal plants dates back thousands of years to the ancient Egyptians, Chinese, Indians and Greeks (Gill, 1999). In recent years, the use of herbs has been gradually increasing due its recorded benefits such as; Antimicrobial, antioxidant, anti-stress, gut micro flora manipulation, nutria-genomics effect and immune enhancement (Guo et al., 2004). Herbal plants are a significant source of various compounds with different biological activities that beneficially promote the growth of producing animals (Davoodi et al., 2010). Therefore, the current study aimed to evaluate the effect of yeast and medicinal plants on animals' production.

\section{MATERIALS AND METHODS}

The experimental study was conducted over a period of 4 months extended from August, 2020 to February, 2021 to evaluate the effect of two natural feed additives on goats added to a basal ration.

\section{1- Selection and management of animals}

Thirty kids were selected in New Valley with growing age $(7 \pm 1)$ months, similar weights within groups $(9-10 \mathrm{~kg})$, castrated males only, all animals were selected in good physical state free from any congenital defects or any infectious diseases and kept in well-ventilated healthy place supplied with clean regulatory changed water.

The animals were subcutaneously injected a dose of (Ivermectin plus Clorsulon) which is broad spectrum anti parasitic in a dose of $1 \mathrm{ml} / 50$ kg.b.w repeated after 21 days. Another method of control is dipping method by the use of (Deltamethrin) which is a highly effective ectoparasitiside with a dose of $0.5 \mathrm{ml} / 1$ litre water.

Introducing the ration according to NRC (4\% of body weight) two times daily with green grass in between, then increased to $6 \%$ divided into three meals each meal cover $2 \%$ of body weight with no green grass in between.

Chemical analysis of the diet, conducted following AOAC (2000) the crud protein was determined by kjeldahl procedure, the crud fat was extracted by (Soxtec System). The Gross Energy content of the dried feed samples was analyzed in bomb calorimeter. 
Table 1: Goat formula presented in 1 ton of ration calculated according to NRC.

\begin{tabular}{cc}
\hline ingredients & Kilograms \\
\hline Corn & 550 \\
\hline Soya bean meal (44\%) & 150 \\
\hline Wheat bran & 100 \\
\hline Clover hay & 170 \\
\hline Calcium carbonate & 20 \\
\hline Na Cl & 10 \\
\hline Premix ${ }^{\circledR} *$ & 4 \\
\hline CPproximated chemical analysis & $\%$ \\
\hline Fat & $15 \%$ \\
\hline Fiber & $3.2 \%$ \\
\hline Ca & $7.5 \%$ \\
\hline P & $1 \%$ \\
\hline Gross energy** & $0.5 \%$ \\
\hline
\end{tabular}

*Premix ${ }^{\circledR}$ : Provided by NACOOP SA Espain (ppm or UI per kilogram of premix): Se,40; I, 250; Co, 80; Cu, 3000; Fe, 6000; Zn, 23 400; Mn, 29 000; S, 60 000; Mg, 60 000; vitamin A, 2000000 UI; vitamin D3, 400 000; vitamin E, 2000ppm; nicotinic acid, 10 000; choline, 20300.

2- Experimental design: animals were divided into three groups according to similar body weights; each group contains 10 goats and received a dose of treatments over 4 months with the exception of control group, and named $\mathrm{A}, \mathrm{B}$ and $\mathrm{C}$.

Yeast supplements: which named group A and its animals received a dose of yeast in the form of tablets, each tablet contains dried yeast extract $66.66 \mathrm{mg}$, (saccharomyces cervicae) equivalent to 500 mg medical yeast, the daily dose was 1 gram (2 tabs.) introduced orally with morning ration.
Herbal supplements: Group B whose animals receive a dose of medicinal plants in the form of capsules, each capsule contains Pollen grains extract powder 200 mg, Treated Nigella sativa (black seed) seeds powder $100 \mathrm{mg}$ and Ginseng dry extract $(10 \%) 50 \mathrm{mg}$. the daily dose was two capsules introduced orally with morning ration.

Control group: Named group $\mathrm{C}$ and consists of 10 kids receiving the same basal ration with no treatments.

Table.2: Daily treatments of kids for $\mathbf{4}$ months with yeast and medicinal plants.

\begin{tabular}{clcc}
\hline Goat group & treatment & dose & $\begin{array}{c}\text { No. of times } \\
\text { daily }\end{array}$ \\
\hline Group A & Yeast. & 2 tabs (1gram) & once / day \\
\hline Group B & Control & & \\
\hline Group C & Medicinal plants & 2 capsules & once / day \\
\hline
\end{tabular}




\section{Animal measurements, sampling and analysis}

Weight gain and feed intake: Measuring of weight gain per each group every 15 days and feed intake of treatment groups compared to control one.

Blood samples: Collection of blood samples in serum tubes for biochemical tests including; liver function tests such as ALT and AST, kidney function tests such as creatinine and BUN and some serum elements such as $\mathrm{P}, \mathrm{Ca}$ and $\mathrm{Mg}$ and evaluated by auto-analyzer (Trinder, 1961).

Ruminal fluid analysis: By using a stomach tube, $5 \mathrm{ml}$ ruminal fluid from each group were randomly collected in $20 \mathrm{cc}$ syringe, and then transported to laboratory for examination. The survival rate was evaluated according to (Nasbimana et al., 2003).

Statistical analysis: Statistical differences were calculated by SPSS with Significance level at $\mathrm{P}<0.05$. All results were analyzed using the procedureof (SAS, 2004).

\section{RESULTS}

Statistical analysis of data in table (3) showed that animal received medicinal plants mixture and yeast showed significant increase in live weight and live weight gain compared with control.

Table 3: Body weights during experiment

\begin{tabular}{cccc}
\hline & control & yeast & $\begin{array}{c}\text { medicinal } \\
\text { plants }\end{array}$ \\
\hline Initial weights & $9.667 \pm 0.33$ & $9.667 \pm 0.33$ & $9.500 \pm 0.28$ \\
\hline $\mathbf{1 / 1 2 / 2 0 2 0}$ & $9.667 \pm 0.33$ & $11.333 \pm 0.33$ & $10.000 \pm 0.57$ \\
\hline $\mathbf{1 5 / 1 2 / 2 0 2 0}$ & $9.667 \pm 0.44$ & $11.500 \pm 0.28$ & $10.833 \pm 0.60$ \\
\hline $\mathbf{1 / 1 / 2 0 2 1}$ & $9.833 \pm 0.16$ & $12.500 \pm 0.50$ & $14.167 \pm 0.88$ \\
\hline $\mathbf{1 5 / 1 / 2 0 2 1}$ & $11.167 \pm 0.33$ & $14.000 \pm 0.57$ & $16.000 \pm 1.15$ \\
\hline $\mathbf{1 5 / 2 / 2 0 2 1}$ & $11.500 \pm 0.28$ & $14.833 \pm 0.72$ & $17.500 \pm 1.15$ \\
\hline $\mathbf{2 8 / 2 / 2 0 2 1}$ & $12.633 \pm 0.46$ & $16.333 \pm 0.23$ & $19.100 \pm 0.57$ \\
\hline
\end{tabular}

Statistical analysis for the obtained data showed in Fig.1 that differences in body weights were significant between the group that received medicinal plants and control group and improvement in the weights of the groups that received yeast supplement compared with control group 


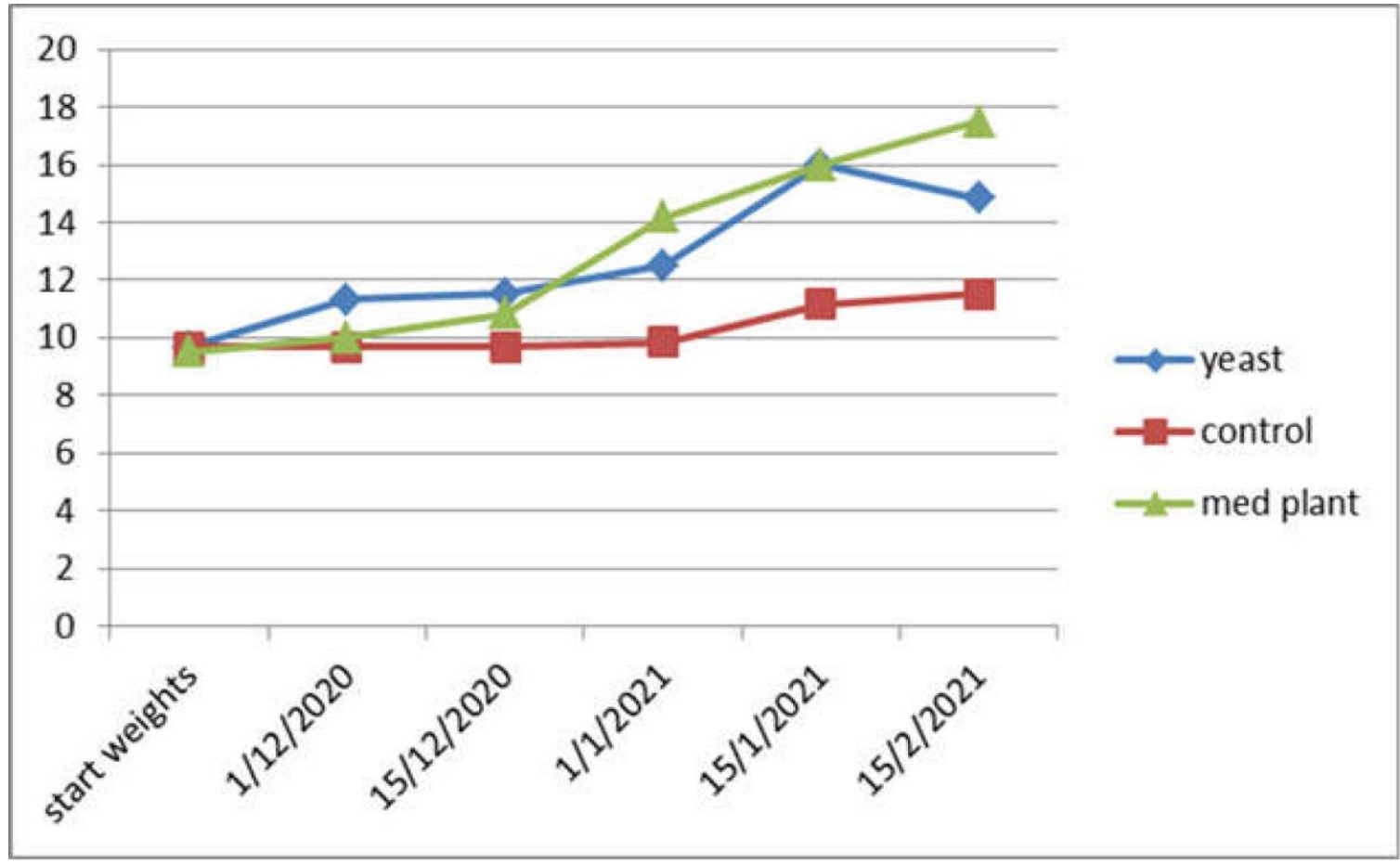

Fig. (1): Differences in body weights between experimental groups throughout the study

The biochemical parameters were in normal physiological state and showed no significant differences in groups received medicinal plants and yeast compared to control group, in addition to normal levels of serum elements except of phosphorus which was significantly affected in group received medicinal plants.

Table 4: Serum biochemical analysis for experimental groups throughout the study

\begin{tabular}{|c|c|c|c|c|c|c|c|c|c|}
\hline & & SGPT & SGOT & urea & BUN & creatinine & $\mathbf{C a}$ & $\mathbf{P}^{*}$ & $\mathbf{M g}$ \\
\hline & Control & $\begin{array}{c}18.367 \\
\pm 0.69\end{array}$ & $\begin{array}{c}53.200 \\
\pm 7.82\end{array}$ & $\begin{array}{c}36.567 \\
\pm 1.91\end{array}$ & $\begin{array}{c}17.087 \\
\pm 0.89\end{array}$ & $\begin{array}{c}.783 \\
\pm 0.05\end{array}$ & $\begin{array}{l}9.500 \\
\pm 0.26\end{array}$ & $\begin{array}{l}3.927 \\
\pm 0.44\end{array}$ & $\begin{array}{l}2.200 \\
\pm 0.06\end{array}$ \\
\hline \multirow[t]{3}{*}{ November } & Yeast & $\begin{array}{c}25.470 \\
\pm 6.27\end{array}$ & $\begin{array}{l}89.600 \\
\pm 12.01\end{array}$ & $\begin{array}{c}34.600 \\
\pm 7.79\end{array}$ & $\begin{array}{c}16.167 \\
\pm 3.64\end{array}$ & $\begin{array}{c}.947 \\
\pm 0.06\end{array}$ & $\begin{array}{c}10.200 \\
\pm 0.66\end{array}$ & $\begin{array}{l}3.857 \\
\pm 0.70\end{array}$ & $\begin{array}{l}2.490 \\
\pm 0.11\end{array}$ \\
\hline & Med.plants & $\begin{array}{c}27.433 \\
\pm 1.02 \\
\end{array}$ & $\begin{array}{r}77.100 \\
\pm 10.88 \\
\end{array}$ & $\begin{array}{c}26.100 \\
\pm 0.20\end{array}$ & $\begin{array}{c}12.197 \\
\pm 0.09 \\
\end{array}$ & $\begin{array}{c}.767 \\
\pm 0.01 \\
\end{array}$ & $\begin{array}{c}11.467 \\
\pm 0.29\end{array}$ & $\begin{array}{l}4.210 \\
\pm 0.55 \\
\end{array}$ & $\begin{array}{l}2.667 \\
\pm 0.13 \\
\end{array}$ \\
\hline & Control & $\begin{array}{c}18.767 \\
\pm 2.72 \\
\end{array}$ & $\begin{array}{r}71.167 \\
\pm 18.56 \\
\end{array}$ & $\begin{array}{c}30.467 \\
\pm 3.27 \\
\end{array}$ & $\begin{array}{c}14.237 \\
\pm 1.53 \\
\end{array}$ & $\begin{array}{c}.773 \\
\pm 0.09 \\
\end{array}$ & $\begin{array}{c}10.500 \\
\pm 0.40 \\
\end{array}$ & $\begin{array}{l}4.310 \\
\pm 0.09 \\
\end{array}$ & $\begin{array}{l}2.300 \\
\pm 0.10 \\
\end{array}$ \\
\hline \multirow[t]{3}{*}{ December } & Yeast & $\begin{array}{c}21.667 \\
\pm 3.51 \\
\end{array}$ & $\begin{array}{c}67.333 \\
\pm 7.17 \\
\end{array}$ & $\begin{array}{c}37.067 \\
\pm 5.44 \\
\end{array}$ & $\begin{array}{l}17.320 \\
\pm 2.54 \\
\end{array}$ & $\begin{array}{r}.720 \\
\pm 0.04 \\
\end{array}$ & $\begin{array}{l}9.967 \\
\pm 0.15 \\
\end{array}$ & $\begin{array}{l}4.857 \\
\pm 0.11 \\
\end{array}$ & $\begin{array}{l}2.510 \\
\pm 0.14 \\
\end{array}$ \\
\hline & Med.plants & $\begin{array}{c}26.833 \\
\pm 1.72\end{array}$ & $\begin{array}{l}81.467 \\
\pm 12.07\end{array}$ & $\begin{array}{c}29.600 \\
\pm 5.75\end{array}$ & $\begin{array}{c}13.830 \\
\pm 2.68\end{array}$ & $\begin{array}{c}.900 \\
\pm 0.10\end{array}$ & $\begin{array}{c}11.333 \\
\pm 0.35\end{array}$ & $\begin{array}{l}7.307 \\
\pm 0.91\end{array}$ & $\begin{array}{l}2.467 \\
\pm 0.03\end{array}$ \\
\hline & Control & $\begin{array}{c}16.567 \\
\pm 1.27\end{array}$ & $\begin{array}{c}82.100 \\
\pm 7.75\end{array}$ & $\begin{array}{c}35.600 \\
\pm 3.67\end{array}$ & $\begin{array}{c}16.637 \\
\pm 1.71\end{array}$ & $\begin{array}{c}.673 \\
\pm 0.16\end{array}$ & $\begin{array}{c}10.267 \\
\pm 0.80\end{array}$ & $\begin{array}{l}3.663 \\
\pm 0.37\end{array}$ & $\begin{array}{l}2.427 \\
\pm 0.11\end{array}$ \\
\hline \multirow[t]{3}{*}{ January } & $\overline{\text { Yeast }}$ & $\begin{array}{c}22.200 \\
\pm 3.20 \\
\end{array}$ & $\begin{array}{l}81.500 \\
\pm 19.21 \\
\end{array}$ & $\begin{array}{c}35.567 \\
\pm 1.29 \\
\end{array}$ & $\begin{array}{c}16.620 \\
\pm 0.60 \\
\end{array}$ & $\begin{array}{c}.663 \\
\pm 0.05 \\
\end{array}$ & $\begin{array}{c}11.533 \\
\pm 0.83 \\
\end{array}$ & $\begin{array}{r}7.513 \\
\pm 1.34 \\
\end{array}$ & $\begin{array}{r}2.333 \\
\pm 0.18 \\
\end{array}$ \\
\hline & Med.Plants & $\begin{array}{c}20.933 \\
\pm 2.33 \\
\end{array}$ & $\begin{array}{c}103.367 \\
\pm 3.45 \\
\end{array}$ & $\begin{array}{c}35.533 \\
\pm 5.07 \\
\end{array}$ & $\begin{array}{l}16.607 \\
\pm 2.37 \\
\end{array}$ & $\begin{array}{c}.763 \\
\pm 0.08 \\
\end{array}$ & $\begin{array}{l}12.467 \\
\pm 0.33 \\
\end{array}$ & $\begin{array}{l}5.810 \\
\pm 0.45 \\
\end{array}$ & $\begin{array}{l}2.733 \\
\pm 0.19 \\
\end{array}$ \\
\hline & Control & $\begin{array}{c}17.600 \\
\pm 4.68\end{array}$ & $\begin{array}{c}90.033 \\
\pm 4.34\end{array}$ & $\begin{array}{c}34.467 \\
\pm 4.22\end{array}$ & $\begin{array}{l}16.107 \\
\pm 1.97\end{array}$ & $\begin{array}{c}.710 \\
\pm 0.08\end{array}$ & $\begin{array}{l}11.467 \\
\pm 1.16\end{array}$ & $\begin{array}{l}3.983 \\
\pm 0.80\end{array}$ & $\begin{array}{c}2.83 \\
\pm 0.20\end{array}$ \\
\hline \multirow[t]{2}{*}{ February } & $\overline{\text { Yeast }}$ & $\begin{array}{c}22.100 \\
\pm 0.92 \\
\end{array}$ & $\begin{array}{r}91.800 \\
\pm 11.92 \\
\end{array}$ & $\begin{array}{c}41.467 \\
\pm 1.91 \\
\end{array}$ & $\begin{array}{c}19.377 \\
\pm 0.89 \\
\end{array}$ & $\begin{array}{c}.633 \\
\pm 0.06 \\
\end{array}$ & $\begin{array}{c}10.833 \pm 0.7 \\
9 \\
\end{array}$ & $\begin{array}{c}5.493 \pm 2 . \\
34\end{array}$ & $2.60 \pm 0.06$ \\
\hline & $\overline{\text { Med.Plants }}$ & $\begin{array}{c}31.133 \\
\pm 4.92\end{array}$ & $\begin{array}{l}132.500 \\
\pm 16.95 \\
\end{array}$ & $\begin{array}{c}35.933 \\
\pm 5.89\end{array}$ & $\begin{array}{c}16.790 \\
\pm 2.75\end{array}$ & $\begin{array}{r}.723 \\
\pm 0.07 \\
\end{array}$ & $\begin{array}{c}13.000 \pm 0.3 \\
1\end{array}$ & $\begin{array}{c}6.853 \pm 1 . \\
01\end{array}$ & $2.90 \pm 0.15$ \\
\hline
\end{tabular}


The examination of liver function including analysis of liver enzymes SGOT and SGPT showed that neither yeast supplementation nor medicinal plants have any significant effects on these enzymes compared with control group.

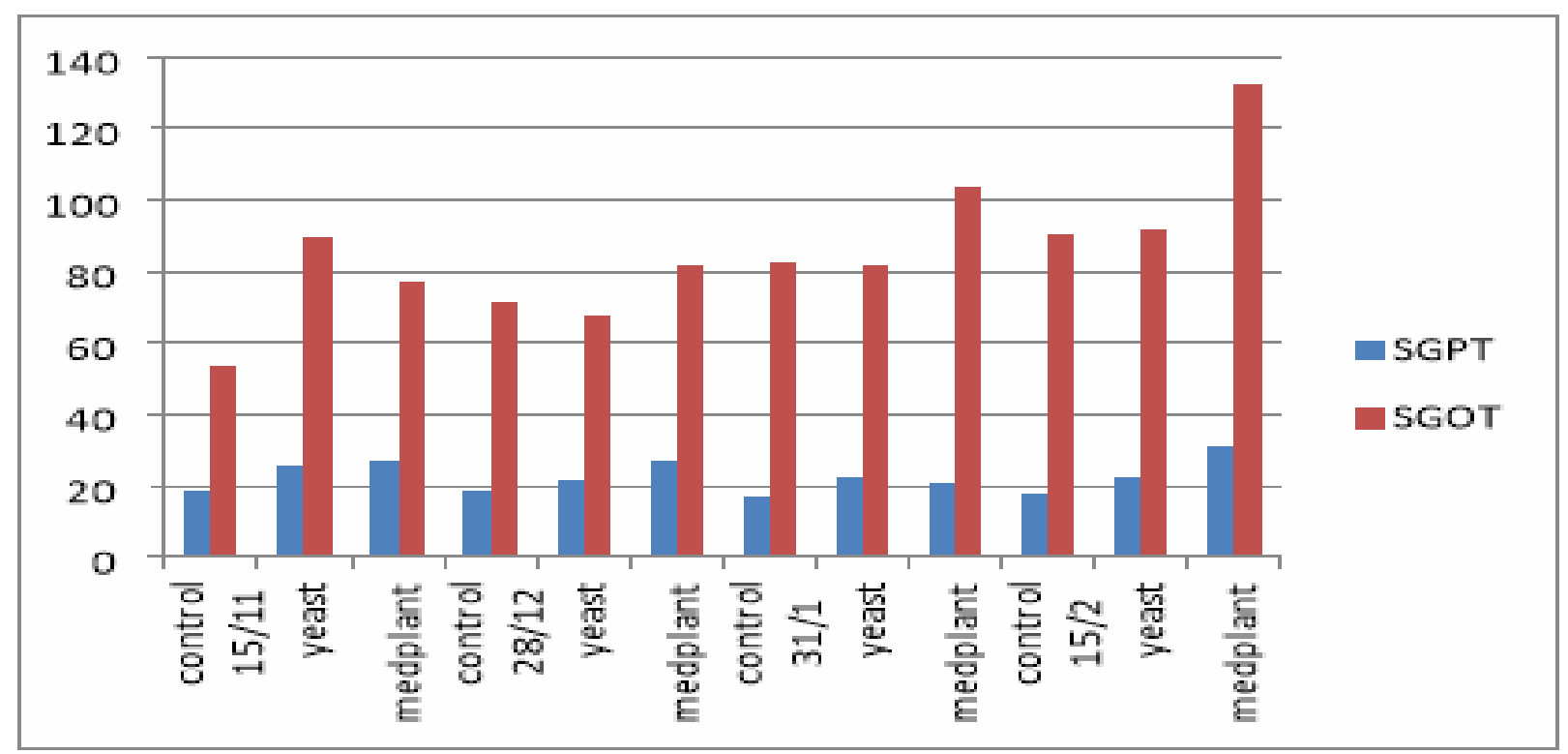

Figure 2: SGPT and SGOT analysis for experimental groups.

For kidney function tests including creatinine and BUN, the supplementations of yeast and medicinal plants had no significant effects on these tests compared with control group.

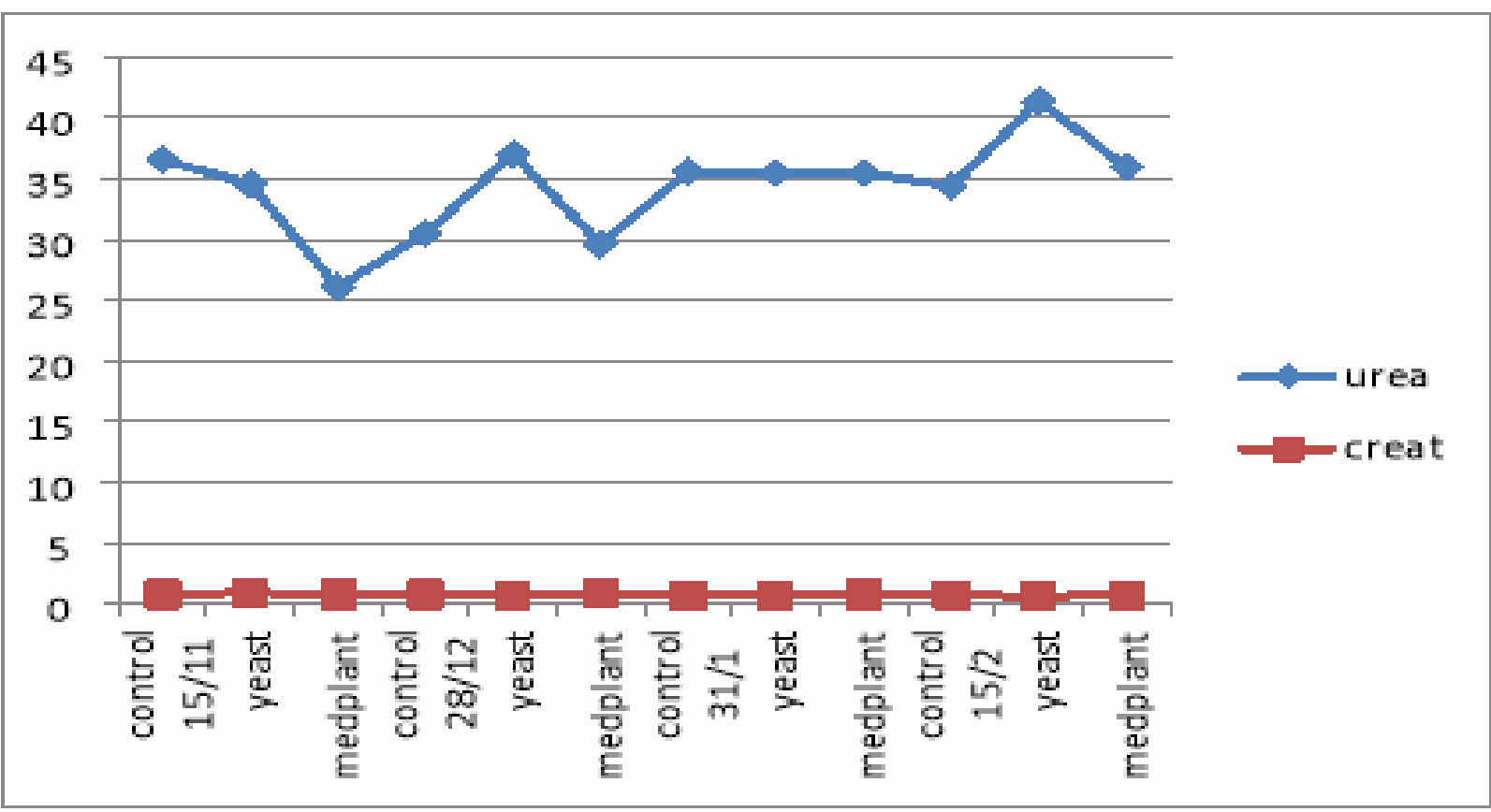

Figure 3: Urea and Creatinine analysis during experiment for experimental groups

The levels of phosphorus for experimental animals showed that no significant differences in yeast group compared with control one, while for those that received medicinal plants, phosphorus levels were significantly increased. 


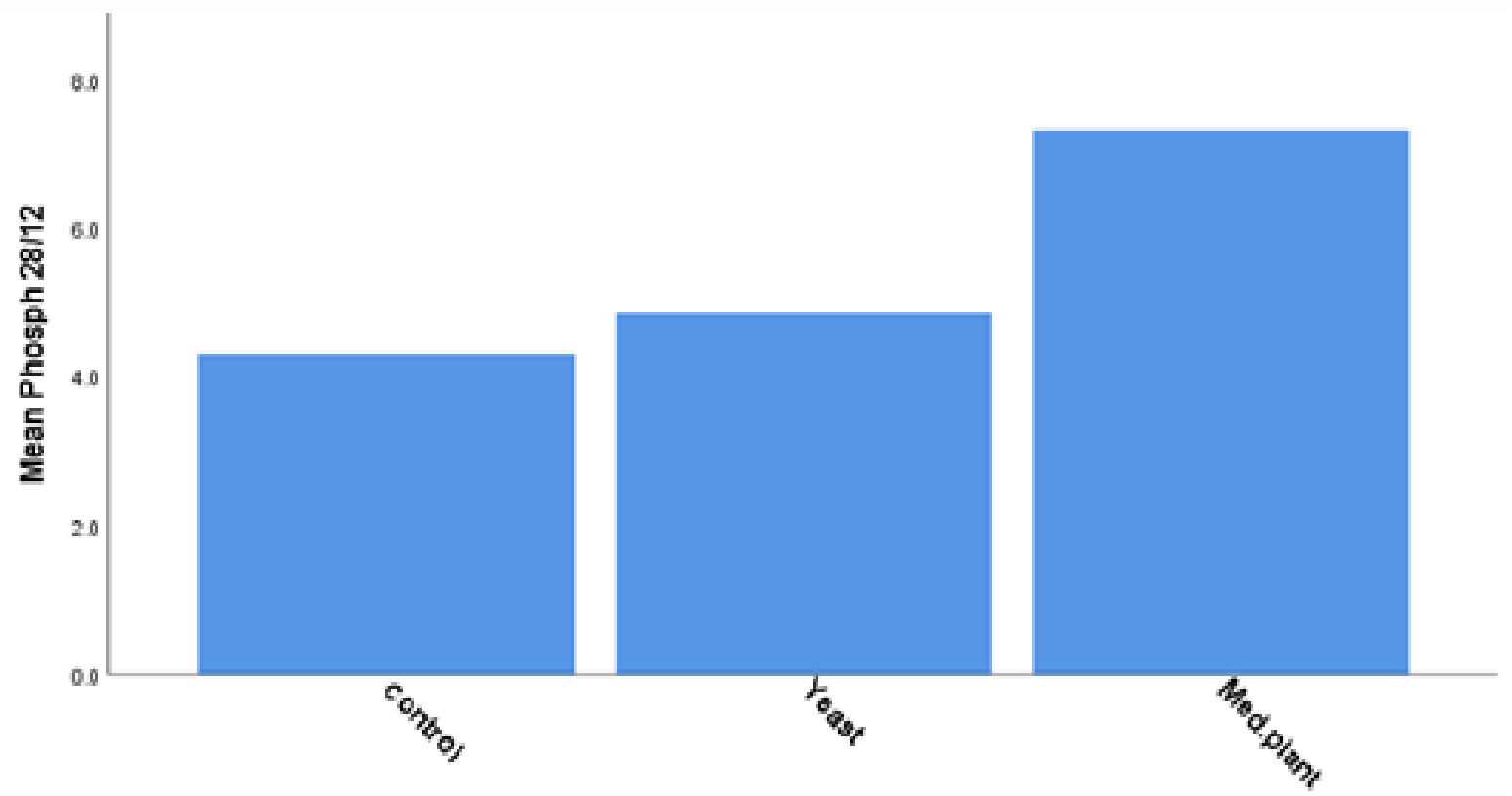

Figure 4: Phosphorus levels throughout the study for experimental groups

Table (5) showed that, the motility and crowdedness of ruminal protozoa were increased due to yeast and medicinal plants mixture $(++++),(+++)$ in compared with control $(++)$.

Table 5: Evaluation of ruminal fluid samples for experimental groups during study

\begin{tabular}{cccc}
\hline & Control & Yeast & Medicinal plants \\
\hline Initial samples & ++ & ++ & ++ \\
\hline $\mathbf{1 / 1 2 / 2 0 2 0}$ & ++ & ++ & ++ \\
\hline $\mathbf{1 5 / 1 2 / 2 0 2 0}$ & ++ & +++ & ++ \\
\hline $\mathbf{1 / 1 / 2 0 2 1}$ & ++ & +++ & +++ \\
\hline $\mathbf{1 5 / 1 / 2 0 2 1}$ & ++ & ++++ & +++ \\
\hline $\mathbf{1 5 / 2 / 2 0 2 1}$ & ++ & ++++ & +++ \\
\hline
\end{tabular}

\section{DISCUSSION}

Studies by Hassan et al. (2008) reported an improvement in live weight gain with diets supplemented with medicinal plants. While other reports by Khadem et al. (2007) had revealed that body weight gain improved using a diet with a yeast culture. Our study agreed with previous studies as the statistical analysis of data in table (3) and fig. 1 showed that animal received medicinal plants mixture and yeast showed significant increase in live weight and live weight gain compared with control.
Previous studies revealed about yeast supplementations by Bullent et al. (2013) and other studies about supplementations of medicinal plants by Habeeb et al. (2009) reported that liver enzymes ALT and AST, in addition to BUN and Creatinine were not significantly affected. This agreed with our results in table (4) and fig. 2 and fig. 3 that revealed no significant differences in SGPT, SGOT, BUN and Creatinine in groups received yeast and medicinal plants compared to control.

Previous studies on serum elements indicated that $\mathrm{Ca}, \mathrm{P}$ and $\mathrm{Mg}$ were in 
physiological states after supplements of yeast by Petr et al. (2010). While other studies showed that there were no significant differences in the concentrations of $\mathrm{Ca}, \mathrm{P}$ and $\mathrm{Mg}$ following supplementation of herbal plants by Salem et al. (1999). From the statistical analysis of our data in table (4) and fig.4 showed that the levels of $\mathrm{Na}, \mathrm{Ca}$ and $\mathrm{Mg}$ were in normal levels in a way that agreed with previous studies except for $\mathrm{P}$ levels that showed increased in the group received medicinal plants compared to control group.

The effect of supplementation of feeds with medicinal plants on rumen ecosystem, studies by Mohamed et al. (2003) and Hassan et al. (2009) indicated a significant improvement in the feed intake and digestibility and also showed that herbal feed additives are beneficially affect gut functions either enzyme or microbial activity. In addition, Hong et al. (1994) indicated that supplementations of yeast had a positive effect on rumen viability and populations of rumen micro flora. From table (5), our evaluation to ruminal fluid samples for groups received yeast and medicinal plants had showed a positive effect on rumen ecosystem when the motility and crowdedness of ruminal protozoa had increased compared with control groups in a way that improved digestibility and rumen viability.

\section{ACKNOWLEDGMENT}

I would like to thank my supervisors who did their best to make this study be successful and help me through the study.

\section{CONCLUSION}

It could be concluded that the use of nutritional yeast and medicinal plants in animal nutrition as a feed additive has a beneficial effect on increasing animal production without side effects of chemicals and drugs as growth promoters with a high safety on animal health.

\section{REFERENCES}

AOAC; 'Official methods of analysis' (2000): 17th edn. (Association of Official Analytical Chemists: Arlington, VA),

Bullent et al., (2013): Effects of dietary live yeast culture on fattening performance on some blood and rumen fluid parameters in goats, article in researchgate may.

Capote J., Sustainable goat breeding and goat farming in the Central and Eastern European Countries. In: Kukovic S, editor. European Regional Conference on Goats.

Davoodi H. (2010): Phytogenics as new class of feed additive in poultry industry. J Anim Vet Adv.9:2295304.

Debrecen (Hungary) and Oradea (Romania), (2017): Rome: FAO; p. 297. Available from: http://www.fao. org/3/a-i5437e.pdf.

Gill C., (1999): Herbs and plant extracts as growth enhancers. Feed International 4, 20-23.

Guo, F.C.; Williams, B.A.; Kwakkel, R.P.; Li, H.S.; Li, X.P.; Luo, J.Y.; Li, W.K. and Verstegen, M.W.A. (2004): Effects of mushroom and herb polysaccharides, as alternatives for an antibiotic, on the cecal microbial ecosystem in broiler chickens. Poultry Science 83,175-182.

Habeeb, A.M.; EL-Gohary, E.S. and ELSaadany, S.A. (2009): Zagazig Veterinary J.; 37(6), 54.

Hassan, SA. and Hassan, KM. (2009b): Effect of different levels of rumen undegradable nitrogen and Nigella Sativa on daily intake, live weight gain, feed conversion ratio and some blood parameters of karadi lambs. Iraqi Journal of Agriculture Science, 40(1):168-178.

Hassan, S.A. and Hassan, K.M. (2008): The effect of supplementation of medicinal plants and probiotic on growth rate and some blood 
parameters of Karadi lambs. Egyptian J. of Nutr. and Feeds. 11 :(In press).

Hong, PH. and Gallaghe, JR. (1994): The effects of yeast supplement on digestibility of low quality roughage fed to sheep. Protocol Australia Soc. Animal Production. 20:398.

Khadem, AA.; Pahlavan, M.; Afzalzadeh, A. and Rezaeian, M. (2007): Effects of live yeast Saccharomyces cerevisiae on fermentation parameters and microbial populations of rumen, total tract digestibility of diet nutrients and on the in situ degradability of alfalfa hay in Iranian Chall sheep. Pak. Journal of Biological Science. 10 (4):590-597.

Khalid, MF.; Sarwar, M.; Nisa, MU. and Rehman, ZU. (2011): Response of growing lambs fed on different vegetable protein sources with or without probiotics. Int $\mathbf{J}$ Agric Biol 13: 332-338; 2011.

Magdy, M. Abu-Ela (2004): Sheep and goat (husbandry and production), Animal and Poultry Production Research Division - Desert Research Center, Ministry of Agriculture and Land Reclamation, General Administration of Agricultural Culture, Bulletin No. $12 /$.

Mohamed, A.H.; EL-Saidy, B.E. and ELSeidi, I.A. (2003): Egyptian J .Nutrition and Feeds; 6(2), 139.

Nasbimana, E.; Kisidayoua, S.; Macheboeuf, A.; Newbold, C. and
Jouany, JP. (2003): App Environ

Microbiol 382-383.

Petr et al., (2010): Effect of feeding yeast culture on ruminal fermentation and blood indicators of Holstein dairy cows, Mendel University Brno, Faculty of Agronomy, Department of Animal Nutrition and Forage production, Brno, Czech Republic.

Rosalee Sinn et al., (2008): Book of raising goats for milk and meat, new revised edition.

Ruf, E.W.; Hale, W.H. and Burroughs, W. (1953): Observations upon an unidentified factor $\mathrm{m}$ feed stuffs stimulatory to cellulose digestion in the rumen and improved live weight gains in lambs. J. Anim. Sci. 12731.

Salem, F.A. and EL-Mahdy, M.R. (1999): The 2nd Int. Conf. on Anim. Prod. \& Health in Semi-Arid Area, North Sinai, Egypt; 161.

SAS (2004): Statistical Analysis Systems. Version 9.2. SAS Institute, Cary, NC.

Trinder, $\quad$ P. (1961): $\quad$ Enzymatic colorimetric method for glucose dedermination. Ann. Clin. Biochem., 6: 24- 39; 1961.

WILLIAMS, P.E.; TAIT, C.A.; INNES, G.M. and NEWBOLD, C.J. (1991): Effects of the inclusion of yeast culture (Saccharomyces cerevisiae plus growth medium) in the diet of dairy cows on milk yield and forage degradation and fermentation patterns in the rumen of steers. J. Anim. Sci. 69, 3016-3026. 
تأثير الخميرة وبعض النباتات الطبية كمحفزات للنمو على الجديان بمحافظة الوادى الجديا

\section{أحد محد خلوى محد ، ياسر فتحى إسعاعيل ، صلاح عبد/لمحسن جلبط}

Email:dr.ahmadkhalwy@gmail.com Assiut University web-site: www.aun.edu.eg

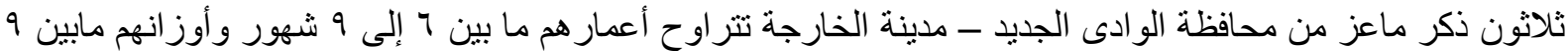

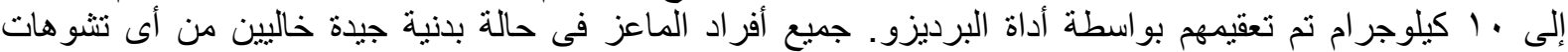

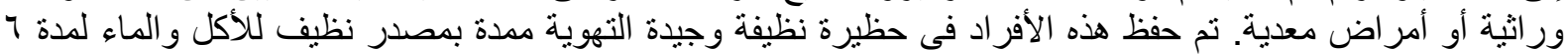

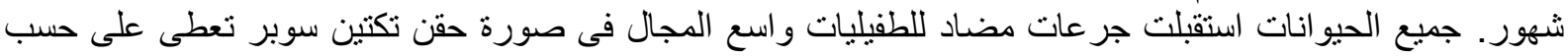

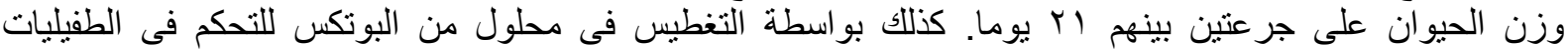

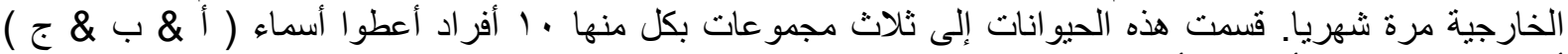

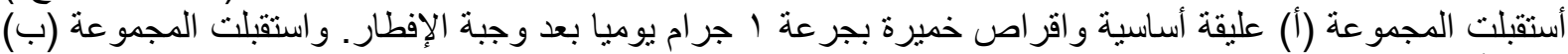

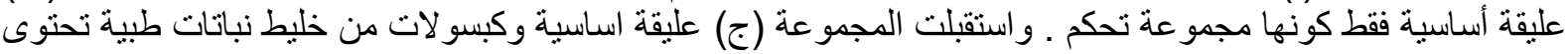

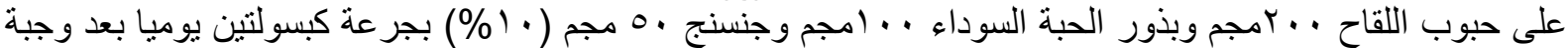

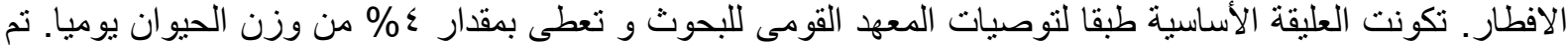

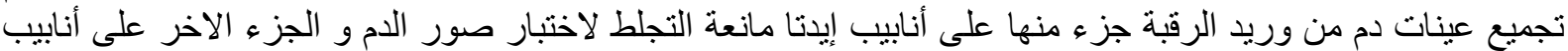

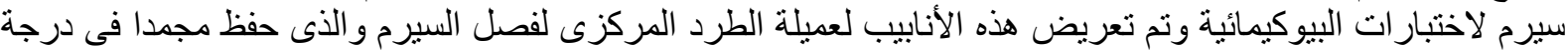

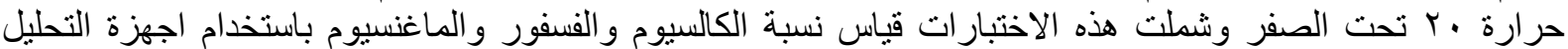

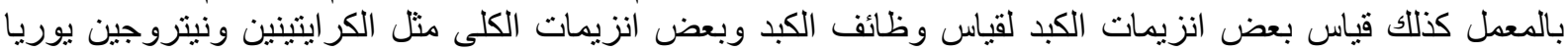

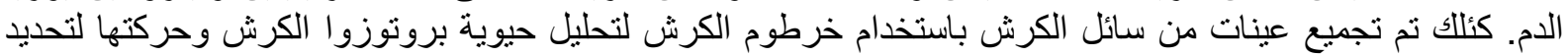

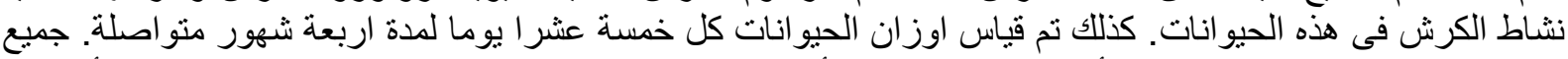

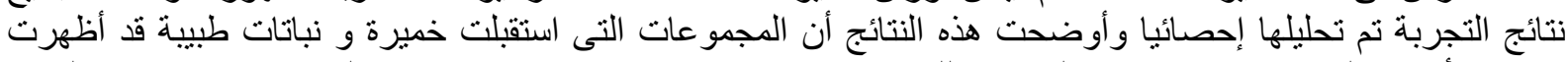

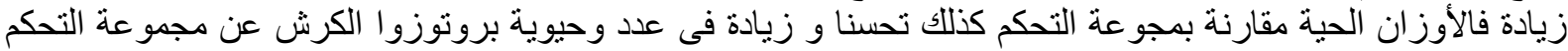

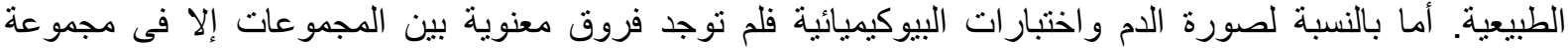
النباتات الطبية والتى اظهرت زيادة فى تركيز الفسفور مقارنة بمجمو عة التحكم. 